\section{PROBLEMS ARISING FROM AN AGEING POPULATION*}

\author{
By DR. L. J. Dublin
}

A

GEING of the American population-a result of due to create serious social and economic problems for the future generations.

If we insist on lightening the burdens on ourselves by reducing the number of our children, we must be prepared to accept the consequences in terms of our social economy. We must be aware of the condition of life we are imposing on our children-namely, an obligation to care for a huge proportion of old people.

Since the beginning of the century, the birth-rate in the United States has decreased by more than one third. Immigration has been drastically cut, and during several recent years more people left the country than entered it. The mortality in the childhood ages is only a fifth of what it was three decades ago. It is these three factors which have shifted the population from youth towards the older ages. In 1850 there were $3,080,000$ people in the United States who were sixty-five years of age or older, or $4 \cdot 1$ per cent of the population. To-day the figure is $8,418,000$ or $6 \cdot 3$ per cent, and in 1980 it is expected to be $22,000,000$, or $14 \cdot 4$ per cent.

In 1980 , the birth-rate and death-rate are expected to meet- 13 births and 13 deaths per 1,000 population -and thereafter the death-rate will be greater than the birth-rate, resulting in a declining population.

The bright side of the picture is in the improvement in death-rate. A century ago a little less than half the babies born in England and Wales were expected to reach the age of fifty. The situation was probably about the same in the United States. In 1938 four out of five male infants and five out of six female babies were expected to reach fifty. The chances of a new-born child reaching age sixty-five are to-day as great as the chances of reaching fifty were only thirty years ago, or about four out of five among white males and two out of three among white females. The continued improvements should ultimately enable three-quarters of the infants born to reach sixty-five.

A recent re-count of a group of persons born about 1876 shows that 20 per cent more lived to the age of fifty than were expected to at the time of their birth, whieh reflects improvement in medicine and in welfare conditions made during their lifetime; 30 per cent of those who to-day are sixty-five or older owe their survival to improvements of this kind made since they were born.

The improvements which have made this greater survival possible are reflected in the changed line-up of the leading causes of death, with tuberculosis, first in 1900, now reduced to seventh, and heart disease (an affliction mainly of the middle-aged and elderly) fourth in 1900 , now elevated to first place. Cancer was the eighth ranking cause of death in 1900 and now it is second. Violence was sixth at the turn of the century and it is now third.

All this means that medical men will have an increasing number of heart and cancer patients and that measures must be intensified to hold these diseases in check. The number of blind and deaf is also due to increase, as will the number of those suffering from mental diseases.

* From a paper read on September 18 at the Bicentennial Conference University of Pennsylvania.

\section{FORTHCOMING EVENT}

\author{
Friday, November I
}

North-East CoAst Institution of Engineers and SHIPBUILders (in the Lecture Theatre of the Mining Institute, Newcastle-upon-Tyne) at 6 p.m.-Prof. W. M. Thornton: "Foundations of the Electrical and Mechanical Transmission of Energy" (Ninth Andrew Laing Lecture).

\section{APPOINTMENTS VACANT}

APPLICATrons are invited for the following appointments on or before the dates mentioned:

RESIDENT LECTURER (WOMAN) IN GEOGRAPHY-The Principal, Training College, Darlington (October 31).

DEPUTY DIRECTOR OF EDUCATION-The Director of Education, Education Office, South Parade, Nottingham (November 2).

Assistant, Grade III (WOMAN), at the Water Pollution Research Laboratory, Watford, Herts.-The Establishment Officer, Department of Scientific and Industrial Research, Teddington, Middx. (quoting 40/10) (November 4).

Assistant Bacteriologist in the Department of Preventive MEDICINE-The Registrar, The TIniversity, Bristol 8 (November 11).

Woman Lecturer in Eddcation-The Principal, Saffron Walden Training College, Saffron Walden, Essex.

Lecturer IN Geography and a Lecturer in Physics able to assist with Teaching of Mathematics-The Registrar, Municipal assist with TEACHIN
College, Portsmouth.

Gradiate Master to teach Science in relation to Bullding and ENGINERRING at the Beckenham Technical Institute--The District Secretary, Kent Education Committee, 12 Beckenham Road, Beckenham.

\section{REPORTS AND OTHER PUBLICATIONS \\ (not included in the monthly Books Supplement)}

\section{Great Britain and Ireland}

Rubber and Agriculture Series, Bulletin No. 14: A Method for the Application of Sodium Chlorate to Bracken. By Dr. G. H. Bates. Pp. 6. (London: British Rubber Publicity Association.) Free. [1010

Proceedings of the Royal Irish Academy. Vol. 46, Section A, No. 4: Maxwell's and Dirac's Equations in the Expanding Universe. By Erwin Schrödinger. Pp. 25-48. 18. Vol. 46, Section A, No. 5 : Notes on the Flectrochemistry of Gases. By $K$. G. Emeleus and Jean W. Beck. Pp. 49-64. 18. Vol. 46, Section A, No.6 : Estimation of the Air-Earth Current. By P. J. Nolan. Pp. 65-76. 18. Vol. 46, Section A, No. 7 : The Equilibrium of Ionisation in the Lower Atmo-
sphere. By J. J. Nolan. Pp. 77-90. 18. Vol. 46, Section A, No. 8: sphere. By J. J. Nolan. Pp. 77-90. 18. Vol. 46, Section A, No. 8: Velocity Distributions in a Field of Force. By W. C. H. Eakin and W. H. McCrea. Pp. 91-102. 18. Vol. 46, Section B, No. 4: River Winifred E. Frost and Arthur E. J. Went. Pp. 53-80. 28. Vol. 46, Winifred E. Frost and Arthur E. J. Went. Pp. 53-80. 28. Vol. 46, Section B, No. 5: Report on a Further Exploration (1929) of the Caves of Keshcorran, Co. Sligo. By A. M. Gwynn, F. T. Riley and A. W. Stelfox. Pp. 81-96. 18. (Dublin: Hodges, Figgis and Co.,
Ltd. ; London: Williams and Norgate, Ltd.)

\section{Other Countries}

U.S. Department of Commerce : National Bureau of Standards, Research Paper RP 1307 : Influence of Cyclic Stress on Corrosion Pitting of Steels in Fresh Water, and Influence of Stress Corrosion on Fatigue Limits. By Dunlap J. McAdam, Jr., and Glenn W. Geil. Pp. 685-722+29 plates. (Washington, D.C.: Government Printing
Office.) 10 cents.

Bulletin of the Raffles Museum, Singapore. No. 15: A Handlist of Malaysian Mammals ; a Systematic List of the Mammals of the Malay Peninsula, Sumatra, Borneo and Java, including the Adjacent Small Islands. By Frederick Nutter Chasen. Pp. xx+209. (Singapore: Government Printing Office.) 5 dollars; 118. 2d. [1010 Annual Report on Forest Administration in Malaya, including Brunei, for the Year 1939. By J. P. Mead. Pp. iv $+100+4$ plates. Brunei, for the Year 1939. By J. P. Mead. Pp. iv $+100+4$ plates.
(Kuala Lumpur: Government Press.) 1 dollar; 2s. 4d. U.S. Office of Education : Federal Security Agency. Bulletin, 1939, No. 13 : Conservation Excursions. By Effie G. Bathurst. Pp. vi+106. 15 cents. Bulletin, 1939, No. 14 : Curriculum Content in Conservation for Elementary Schools. By Effie G. Bathurst. Pp. vi +80 . 15 cents. (Washington, D.C. : Government Printing
Office.)

U.S. Department of Agriculture. Circular No. 561: Importation Rearing and Colonization of Parasites of the Oriental Fruit Moth. By H. W. Allen, J. K. Holloway and G. J. Haeussler. Pp. 62. 10 cents Technical Bulletin No, 702: Selenium Occurrence in Certain Soils in the United States, with a Discussion of Related Topics: Fourth Report. By K. T. Williams, H. W. Lakin and Horace G. Byers. Pp. 60. 10 cents. (Washington, D.C.: Government Printing

$[1410$ 